\title{
Routine genetic testing of lung cancer specimens derived from surgery, bronchoscopy and fluid aspiration by next generation sequencing
}

\author{
GOU YAMAMOTO $^{1}$, MARI KIKUCHI ${ }^{1 *}$, SHIHO KOBAYASHI ${ }^{1 *}$, YOSHIKO ARAI ${ }^{1}$, KENJI FUJIYOSHI ${ }^{1,4}$, \\ TOMOKAZU WAKATSUKI $^{1}$, MIHO KAKUTA ${ }^{1}$, YUKI YAMANE ${ }^{2}$, YOSHIHITO IIJIMA ${ }^{3}$, HIDEAKI MIZUTANI ${ }^{2}$, \\ YUKI NAKAJIMA $^{3}$, JUNKO SUDO ${ }^{2}$, HIROYASU KINOSHITA ${ }^{3}$, FUTOSHI KURIMOTO ${ }^{2}$, HIROHIKO AKIYAMA ${ }^{3}$, \\ HIDETAKA URAMOTO ${ }^{5}$, HIROSHI SAKAI ${ }^{2}$, YOSHITO AKAGI ${ }^{4}$ and KIWAMU AKAGI ${ }^{1}$
}

\author{
Departments of ${ }^{1}$ Molecular Diagnosis and Cancer Prevention, ${ }^{2}$ Thoracic Oncology and ${ }^{3}$ Thoracic Surgery, \\ Saitama Cancer Center, Ina, Kitaadachi, Saitama 362-0806; ${ }^{4}$ Department of Surgery, Kurume University, \\ Kurume, Fukuoka 830-0011; ${ }^{5}$ Department of Thoracic Surgery, School of Medicine, \\ Kanazawa Medical University, Uchinaka, Kahoku, Ishikawa 920-0293, Japan
}

Received November 14, 2016; Accepted February 10, 2017

DOI: $10.3892 /$ ijo.2017.3935

\begin{abstract}
After the development of EGFR tyrosine kinase inhibitors (TKIs), genetic testing of EGFR became required for effective treatment of lung cancer. Initially, the testing was conducted separately for each mutated region. However, many $E G F R$ mutations have since been identified that determine the efficacy of EGFR-TKIs. Therefore, genetic testing of EGFR by next generation sequencing (NGS) may be a suitable strategy for lung cancer. Here we examined the applicability of the NGS method in regard to sensitivity, time and cost. A total of 939 specimens were obtained from 686 lung cancer patients at our hospital. DNA and RNA were simultaneously extracted from specimens derived from surgery, bronchoscopy, and fluid aspiration. Specimens included cerebrospinal fluid, pleural effusion, abdominal fluid, and pericardial effusion. From RNA, target regions ( $E G F R, K R A S, A L K$ fusion and $R E T$ fusion) were enriched by RT-PCR and sequenced with MiSeq. From DNA, PCR or PCR-RFLP conventional methods were performed. NGS and conventional methods were carried out routinely per week. Among the total 939 specimens, 38 specimens could not be examined with NGS. Among these, 34 specimens were analyzed by conventional testing with simultaneously extracted DNA. The remaining four specimens
\end{abstract}

Correspondence to: Dr Kiwamu Akagi, Department of Molecular Diagnosis and Cancer Prevention, Saitama Cancer Center, 780 OazaKomuro, Ina, Kitaadachi, Saitama 362-0806, Japan

E-mail: akagi@cancer-c.pref.saitama.jp

*Contributed equally

Key words: EGFR, KRAS, molecular-targeted therapy, genetic testing, next-generation sequencing, precision medicine could not be tested with either method. Compared with the conventional method, the concordance rate of mutations was 99\% (892/901), excluding specimens with NGS failure. The time period required from processing of specimens to results was 4 days, and the cost per sample was sufficiently low. In conclusion, the genetic testing with NGS method was useful for lung cancer treatment. The cost, sensitivity and time were able to tolerate routine examinations.

\section{Introduction}

Lung cancer is one of the most common cancers and the leading cause of cancer-related death worldwide (1). Non-small cell lung cancer (NSCLC) accounts for $80 \%$ of lung cancer and is classified broadly in adenocarcinoma (AdCa) and squamous cell carcinoma (SCC). Approximately half of NSCLC cases are $\mathrm{AdCa}$ (2). A decade ago, therapeutic strategies for lung cancer were histologically classified only as small-cell carcinoma (SCLC) or NSCLC. However, in recent years, somatic mutations within the epidermal growth factor receptor $(E G F R)$ gene were discovered as driver mutations in lung cancer, thus dramatically changing the therapeutic strategy for unresectable lung cancer (3). Driver mutations are a predictive factor of the effect of EGFR tyrosine kinase inhibitors (TKI), which are molecular-targeted agents (such as gefitinib, erlotinib, and afatinib). The response rate of these drugs against cancers harboring driver mutations is $>70 \%$ in many studies $(4,5)$. Moreover, rearrangement of the anaplastic lymphoma receptor tyrosine kinase $(A L K)$ gene (6) was also found to predict the response to ALK inhibitors (crizotinib and alectinib) (7). Thereafter, rearrangements of ret proto-oncogene $(R E T)$ and ROS proto-oncogene 1, receptor tyrosine kinase (ROS1) genes (8) were revealed as predictors for NSCLC. The molecular-targeted therapies crizotinib and vandetanib were used to target cancers harboring these two rearrangements $(9,10)$. An ALK TKI regimen, targeted against cancer 


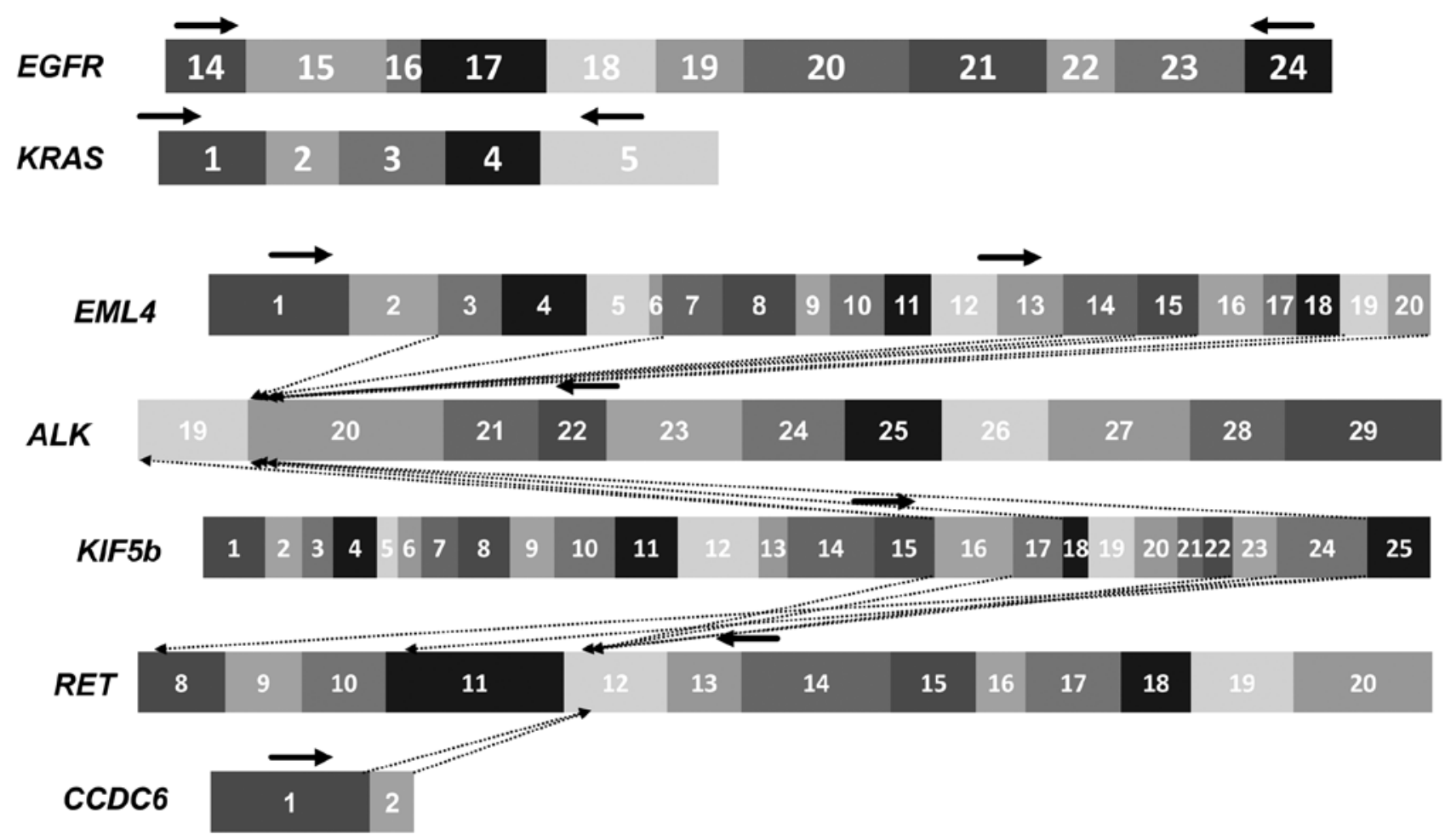

Figure 1. Primer design in target genes. Black arrows indicate positions of designed primers. White numbers indicate exon numbers of each gene. Dotted lines indicate regions of gene fusion.

harboring $A L K$ rearrangement, was approved shortly after the discovery of $A L K$ rearrangement. This compares with the standard approval time of therapeutic drugs of $>10$ years. This early approval suggests that an agent targeted to gene alterations (molecular-targeted agent) is also likely to be approved quickly in expectation of a high antitumor effect.

Precise patient classification is necessary to determine the most appropriate therapeutic strategy and obtain the maximum effect of molecular target drugs. Several EGFR mutations were initially found to influence the efficacy and administration of TKIs, but currently over 10 types of mutations have been shown impact the efficacy of TKIs. In addition, many mutations other than those in the EGFR gene are used to select a method of treatment (11). Previously, companion diagnostics for gene mutations that impacted the success of anticancer drugs were conducted separately for each mutation, followed by other diagnostics. However, choosing the appropriate molecular targeted drug now requires an extensive analysis of gene regions. Many institutions are using next generation sequencing (NGS) methods to detect comprehensive gene mutations associated with lung cancer treatment (12-14). However, genetic testing performed by NGS is fraught with problems of sensitivity, complexity and cost. Comparisons of the sensitivity of conventional methods using NGS and analysis from non-surgical specimens such as bronchoscope lavage and pleural effusion have not been reported.

In this study, we obtained 939 surgical, biopsy, bronchoscope, and fluid aspiration specimens from 686 lung cancer patients and examined the sensitivity and efficiency of NGS analyses using RNA (15) compared with conventional analytical methods (PCR-RFLP and RT-PCR) using DNA (16).

\section{Materials and methods}

Samples. This study included a total of 686 patients suspected with lung cancer at Saitama Cancer Center. All patients provided informed consent. A total of 939 specimens were obtained by surgery, bronchoscopy and fluid aspiration, and submitted for genetic testing at a specialized department in our hospital. Genetic tests were carried out only once for each patient, which is typical in Japan. Control DNA containing EGFR T790M (Riken Genesis, Japan) was used for a comparison of sensitivity between NGS and conventional methods.

Testing workflows. DNA and RNA were extracted simultaneously from all specimens using the AllPrep DNA/RNA Micro kit (Qiagen, Hilden, Germany). From extracted RNA, cDNA was synthesized with both oligo-dT and random primers using the SuperScript First-Strand Synthesis system for RT-PCR (Thermo Fisher Scientific, Waltham, MA, USA). Conventional examination of the EML4-ALK fusion gene (RT-PCR method) was performed with part of the cDNA. The remaining cDNA sample was used for multiplex PCR for targeted $E G F R$ (exons 15-23), KRAS (all coding regions), EML4/KIF5b-ALK and KIF5b/CCDC6-RET (Fig. 1) using the Takara Taq ${ }^{\text {TM }}$ Hot Start Version (Takara Bio, Japan). The PCR conditions were as follows: $E G F R$ and $K R A S, 95^{\circ} \mathrm{C}$ for $3 \mathrm{~min}$, followed by 40 cycles of $95^{\circ} \mathrm{C}$ for $30 \mathrm{sec}, 57^{\circ} \mathrm{C}$ for $30 \mathrm{sec}$ and $72^{\circ} \mathrm{C}$ for $90 \mathrm{sec}$, and finally $72^{\circ} \mathrm{C}$ for $5 \mathrm{~min}$; for multiplex PCR, $95^{\circ} \mathrm{C}$ for $3 \mathrm{~min}$, followed by 40 cycles of $95^{\circ} \mathrm{C}$ for $30 \mathrm{sec}, 60^{\circ} \mathrm{C}$ for $30 \mathrm{sec}$ and $72^{\circ} \mathrm{C}$ for $105 \mathrm{sec}$, and finally $72^{\circ} \mathrm{C}$ for $5 \mathrm{~min}$. Primer sequences are shown in Table I. PCR products were purified with the QIAquick PCR Purification kit (Qiagen) and quan- 
Table I. Primer sequence.

\begin{tabular}{llc}
\hline Primers & \multicolumn{1}{c}{ Sequence (5'-3') } & Product length (bp) \\
\hline $\begin{array}{l}E G F R \text { forward } \\
E G F R \text { reverse }\end{array}$ & GAACATCACCTGCACAGGACG & 1,148 \\
\hline$K R A S$ forward & ATCTGCGTCTATCATCCAGC \\
$K R A S$ reverse & CATTTCGGACTGGGAGCGAG & 836 \\
\hline$E M L 4$ forward-1 & CTGGGAATACTGGCACTTAGAGG & Variable \\
$E M L 4$ forward-2 & CCGGCAGTCTCGATGATAG & $344-2,305$ \\
$K I F 5 B$ forward & TGGAGTAGGATGCCTGGATT forward & AAATGACCAACCACCAGAAA \\
$A L K$ reverse & TGCAGCAAGAGAACAAGGTG & \\
$R E T$ reverse & ATCCAGTTCGTCCTGTTCAGAGC & \\
\hline
\end{tabular}

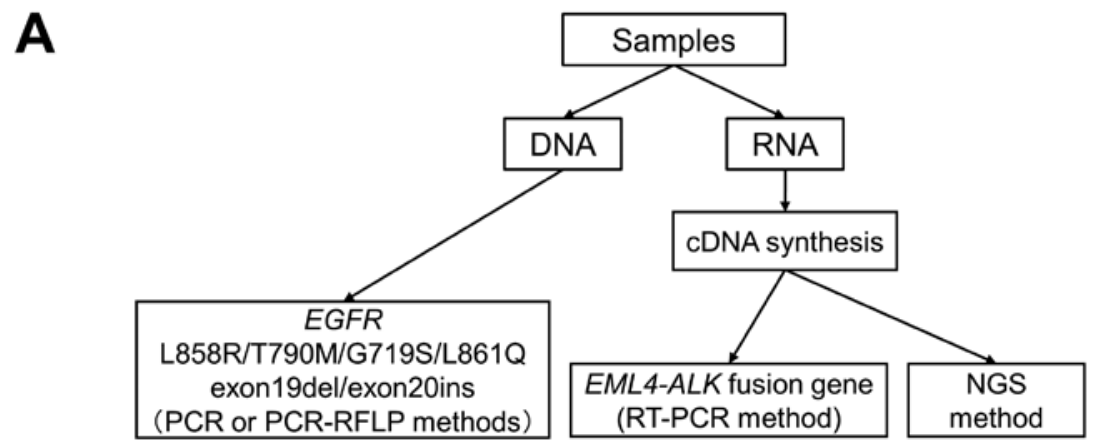

B

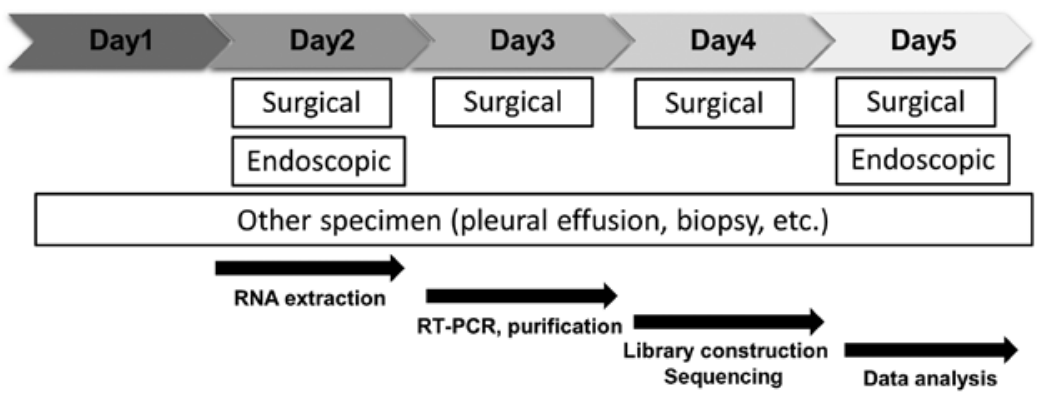

Figure 2. Overview of genetic testing. (A) DNA was used for the conventional method. RNA was used for both conventional and NGS methods. (B) Surgical indicates surgical materials. Endoscopic indicates bronchoscope lavage.

tified with the Qubit ds DNA HS assay kit (Thermo Fisher Scientific). Purified and quantified PCR products were mixed at equal molar ratios. Because multiplex PCR products were not amplified in most cases for fusion genes, reflecting their rarity, they could not be quantified. However, NGS is very sensitive and sometimes detects fusion genes. Therefore, in unquantifiable cases, $10 \mu \mathrm{l}$ fusion gene PCR product was mixed. Mixed PCR products were quantified again, and libraries for NGS were prepared using the Nextera XT DNA Sample Prep kit (Illumina, San Diego, CA, USA) according to the manufacturer's protocol. Assessments of quality and quantification of libraries were performed with the D1000 Screen Tape system (Agilent, Santa Clara, CA, USA) and Qubit ds DNA HS assay kit (Thermo Fisher Scientific), respec- tively. Constructed libraries were adjusted to $4 \mathrm{nM}$ and were sequenced using MiSeq (Illumina) with the MiSeq Reagent Kit Nano v2 (300 cycles, Illumina). Extracted DNA was used for conventional testing (Fig. 2A) (16). The overview of the genetic testing strategy performed each week by NGS method is shown in Fig. 2B.

Verification of discrepancy by NGS panel. Samples showing different results between the conventional method and NGS method were verified using the TruSight Tumor 15 (TST15, Illumina) with DNA according to the manufacturer's protocol. Several samples containing lower concentrations of DNA specified by the protocol $(2 \mathrm{ng} / \mu \mathrm{l})$ were only used to prepare libraries. 
Table II. Patient characteristics.

\begin{tabular}{|c|c|c|}
\hline & $\mathrm{N}=686$ & $(\%)$ \\
\hline \multicolumn{3}{|l|}{ Median age } \\
\hline Years & 68.4 & \\
\hline (range) & $(28-91)$ & \\
\hline \multicolumn{3}{|l|}{ Gender } \\
\hline Male & 447 & $(65)$ \\
\hline Female & 239 & $(35)$ \\
\hline \multirow{2}{*}{\multicolumn{3}{|c|}{$\begin{array}{l}\text { Smoking status } \\
\text { (Brinkman index) }\end{array}$}} \\
\hline & & \\
\hline$\geq 800$ & 236 & $(34)$ \\
\hline$<800$ & 51 & (7) \\
\hline$<600$ & 44 & (6) \\
\hline$<400$ & 24 & (3) \\
\hline$<200$ & 12 & (2) \\
\hline Index unknown (smoker) & 57 & (8) \\
\hline Never & 203 & $(30)$ \\
\hline Smoking status unknown & 59 & (9) \\
\hline \multicolumn{3}{|l|}{$\begin{array}{l}\text { Histology available } \\
(\mathrm{N}=321)\end{array}$} \\
\hline Adenocarcinoma & 169 & $(25)$ \\
\hline $\mathrm{SCC}$ & 62 & (9) \\
\hline Other NSCLC & 5 & (1) \\
\hline Small & 8 & (1) \\
\hline Atypical lesion & 4 & (1) \\
\hline Benign tumor & 2 & (1) \\
\hline Carcinoma (undifined) & 34 & (5) \\
\hline \multicolumn{3}{|l|}{ Metastatic lung cancer } \\
\hline Colorectal cancer & 15 & (2) \\
\hline Other site & 17 & (2) \\
\hline $\begin{array}{l}\text { No tumor cells } \\
\text { (inflammatory tissue etc.) }\end{array}$ & 5 & (1) \\
\hline \multicolumn{3}{|l|}{$\begin{array}{l}\text { Cytology only } \\
(\mathrm{N}=365)\end{array}$} \\
\hline Class I & 0 & \\
\hline Class II & 92 & (13) \\
\hline Class III & 40 & (6) \\
\hline Class IV & 16 & (2) \\
\hline Class V & 208 & $(30)$ \\
\hline Not classified & 9 & (1) \\
\hline
\end{tabular}

Sequence data analysis. Data output in the FASTQ format by MiSeq were analyzed with CLC Genomics Workbench (Qiagen). FASTQ files were trimmed by quality value, mapped and realigned to reference sequence (hg19), called variants. Variants with allele frequency of $\geq 1 \%$, allele count of $\geq 3$ and that covered $\geq 300$ reads were listed. Target ratios exceeded $95 \%$ and minimum coverage of analyzing regions was $>500$. Detected variants were annotated from databases such as dbSNP, HapMap, ThousandGenome, HGVD (17),
Table III. Summary of obtained samples from lung cancer patients.

\begin{tabular}{|c|c|c|c|}
\hline \multirow[b]{2}{*}{ Sample type } & \multicolumn{3}{|c|}{ RNA concentration } \\
\hline & $\begin{array}{c}\text { No. of } \\
\text { samples }\end{array}$ & $\begin{array}{c}\text { Average } \\
(\mathrm{ng} / \mu \mathrm{l})\end{array}$ & $\begin{array}{c}\text { No. of samples } \\
<20\end{array}$ \\
\hline Bronchoscope lavage & $413(18)$ & 4.5 & 403 \\
\hline Surgery & $311 \quad(2)$ & 18.3 & 46 \\
\hline Biopsy & $77 \quad(2)$ & 13.9 & 33 \\
\hline Pleural effusion & $83 \quad(7)$ & 16.1 & 29 \\
\hline Cerebrospinal fluid & $18 \quad(3)$ & & \\
\hline Ascites fluid & 5 & & \\
\hline Sputum & $3(1)$ & & \\
\hline Pericardial effusion & 2 & & \\
\hline Others & $27 \quad(5)$ & 8.2 & 19 \\
\hline Total & $939(38)$ & & \\
\hline
\end{tabular}

ToMMo (18), Clinver, and COSMIC. Candidates for fusion genes were acquired by a list of broken pairs and were validated by mapping directly to sequences of fusion genes and RT-PCR method. FASTQ files obtained from the NGS panel for verification were also analyzed with CLC Genomics Workbench. Variant data were visualized with OncoPrimter (cBioPortal; http://www.cbioportal.org/) $(19,20)$.

\section{Results}

Patient characteristics. A total of 686 patients were included in this study and 939 specimens were obtained. Patient characteristics are presented in Table II. Of the total patients, 321 were categorized according to histopathological type. AdCa accounted for $53 \%$ of pathologically defined cases, followed by SCC (19\%). Thirty-two cases showed lung metastasis from cancer of other organs. In 365 patients, only cytological specimens were examined and more than half the specimens were diagnosed as class 4 or 5 . The cytology cases included patients that previously underwent surgery before this study and were pathologically diagnosed.

Summary of specimens. Among the total 939 specimens, $\sim 44 \%$ were obtained by bronchoscopic examination and these specimens showed low RNA concentrations compared with other specimens (Table III). Thirty-eight specimens (4\%) could not be examined with NGS because of PCR failure, although 34 of these specimens could be examined by conventional testing with simultaneously extracted DNA. The remaining four specimens could not be tested with either method. Unanalyzable specimens included bronchoscope lavage with few cells, cerebrospinal fluid, hemorrhagic pleural effusion and surgical material containing mostly necrotic debris. The time period required for reporting of results from processing of specimens was 4 days. 


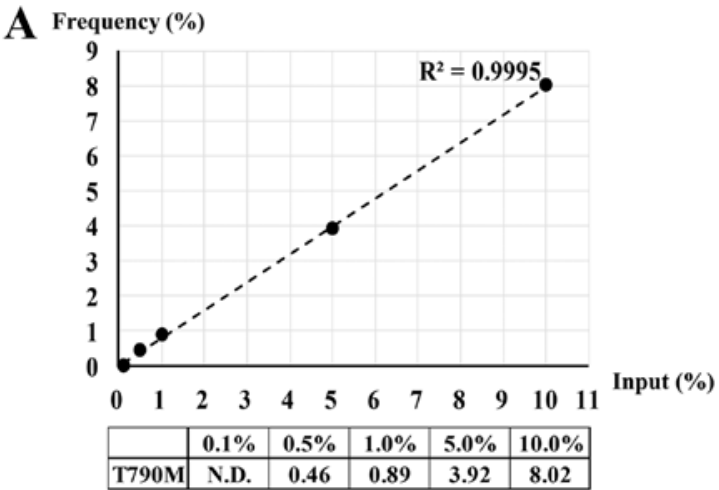

B

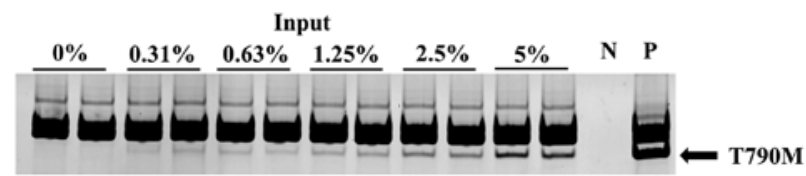

Figure 3. Sensitivity of NGS and conventional methods. (A) NGS method. $\mathrm{y}$-axis indicates input amount of T790M mutation. X-axis indicates detected frequency of the mutation. Table shows the actual number. (B) Conventional method. $\mathrm{N}$, negative control $\left(\mathrm{H}_{2} \mathrm{O}\right), \mathrm{P}$, positive control ( $\mathrm{H} 1975$ cells).

Comparison of sensitivity between conventional and NGS methods using T790M harboring H1975 cells. Sensitivity of mutation detection was compared between NGS and conventional methods (PCR-RFLP method). First, a dilution series of control DNA was examined for detection of EGFR T790M using each method. The NGS method could detect up to $0.5 \%$ of T790M mutation, while the conventional method could detect explicitly up to $0.63 \%$ (Fig. 3).

Distribution of EGFR and KRAS mutations, and fusion genes in lung cancer. Among the total 686 patients, 411 were diagnosed pathologically as AdCa or strongly suspected as AdCa. These cases included cytological specimens diagnosed as class 4 or 5 from patients previously decided as AdCa. Typical EGFR TKI-sensitizing mutations (ex19del, L858R, G719X, L861Q) were detected in $32 \%$ of these cases, and fusion genes (ALK, RET) were detected in $2.4 \%$ of cases (Fig. 4A). The most common mutations in the KRAS gene were found in exon 2 (exon 2; G12X or G13X, 13\% of cases), followed by mutations in exon 3 (exon 3; Q61L or Q61H, 2.4\%). Only one case harbored mutation in exon 4 (A146T). EGFR mutations were detected in $40 \%$ of cases pathologically diagnosed as $\mathrm{AdCa}$ or as strongly suspected AdCa by surgical materials alone (Fig. 4B). Fusion genes were detected in 11 cases among all patients (Table IV).

Among the EGFR exon 19 deletions, a 15-bp deletion from p.K745 to p.A750 was most frequently observed (Table V). Exon 20 insertion mutations were different in all cases. One exon 19 deletion was found in squamous papilloma. No EGFR and $K R A S$ mutations or fusion genes were detected in SCC cases.

Discordance of results between conventional and NGS methods. Among the 901 specimens with results obtained by both conventional and NGS methods, 9 cases showed varied results between the two methods (Table VI). Almost all cases

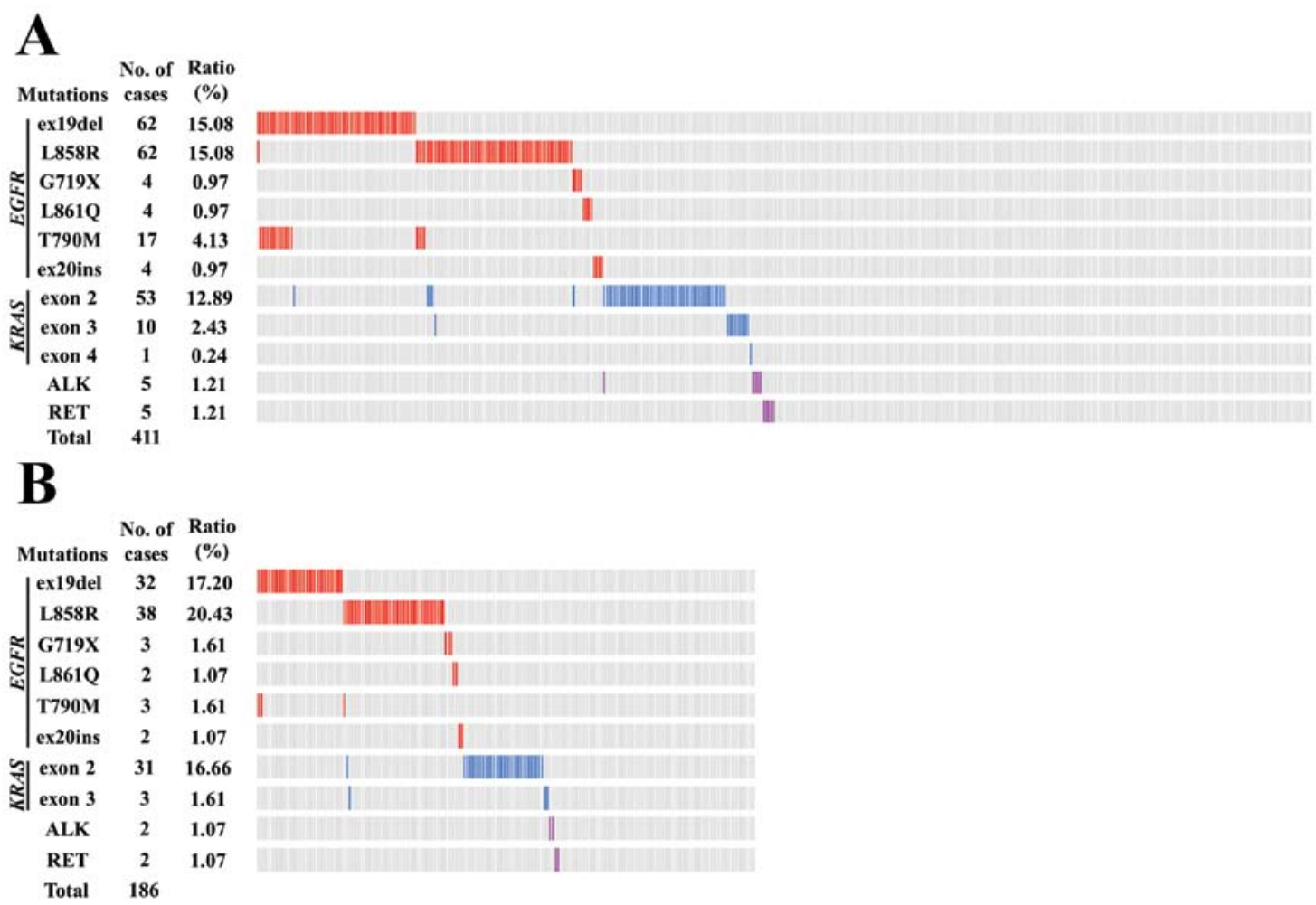

Figure 4. Frequency and distribution of mutations. Plot of mutations of (A) pathologically diagnosed AdCa or strongly suspected AdCa according to all materials ( $\mathrm{n}=411)$, and (B) by surgical material alone (n=186). ex19del, L858R, G719X, L861Q, T790M and ex20ins; mutations of EGFR, exons 2-4; mutation of $K R A S, A L K$ and RET fusion genes. 
Table IV. Fusion genes.

\begin{tabular}{|c|c|c|c|c|c|}
\hline Gender & Sample type & RNA concentration $(\mathrm{ng} / \mu \mathrm{l})$ & Cytology & Histology & Fusion genes \\
\hline M & BL & 33.9 & $\mathrm{~V}$ & & CCDC6-RET \\
\hline M & $\mathrm{AF}$ & 2.5 & $\mathrm{~V}$ & & $E M L 4-A L K$ \\
\hline M & PE & 20 & $\mathrm{~V}$ & & $E M L 4-A L K$ \\
\hline $\mathrm{F}$ & Surgery & 20 & & $\mathrm{AdCa}$ & $E M L 4-A L K$ \\
\hline M & Surgery & 20 & & $\mathrm{AdCa}$ & $E M L 4-A L K$ \\
\hline $\mathrm{F}$ & BL & 7.4 & $\mathrm{~V}$ & & $E M L 4-A L K$ \\
\hline $\mathrm{F}$ & Surgery & 20 & & $\mathrm{AdCa}$ & $K I F 5 b-R E T$ \\
\hline $\mathrm{F}$ & $\mathrm{PE}$ & 20 & $\mathrm{~V}$ & & CCDC6-RET \\
\hline M & Biopsy & 20 & $\mathrm{~V}$ & & CCDC6-RET \\
\hline M & Biopsy & 1.6 & \multicolumn{2}{|c|}{ Unknown } & $E M L 4-A L K$ \\
\hline M & $\mathrm{BL}$ & 2 & $\mathrm{~V}$ & & $K I F 5 b-R E T$ \\
\hline
\end{tabular}

BL, bronchoscope lavage; AF, ascites fluid; PE, pleural effusion.

Table V. EGFR insertions/deletions.

\begin{tabular}{llr}
\hline Types of insertion/deletion & \multicolumn{1}{c}{ Sequence of insertion/deletion } & No. of cases \\
\hline Exon 19 deletion & & 29 \\
p.Lys745_Ala750delinsLys & GGAATTAAGAGAAGC & 11 \\
p.Glu746_Ala750del & GAATTAAGAGAAGCA & 5 \\
p.Leu747_Pro753delinsSer & TAAGAGAAGCAACATCTC & 5 \\
p.Glu746_Ser752delinsVal & delAATTAAGAGAAGCAACATCinsT & 15 \\
p.Glu746_Thr751delinsGlu & ATTAAGAGAAGCAAC & 18 \\
p.Glu746_Arg748del & GAATTAAGA & 3 \\
p.Leu747_Ser752del & TTAAGAGAAGCAACATCT & 1 \\
p.Lys745_Ala750delinsLys & delCAAGGAATTAAGAGAAGCinsTAA & 1 \\
p.Glu746_Thr751delinsAla & AATTAAGAGAAGCAA & 1 \\
p.Glu746_Ala750delinsGlnPro & delGAATTAAGAGAAGinsCAAC & 1 \\
p.Glu746_Ser752delinsLeu & delGAATTAAGAGAAGCAACATCinsCT & 18 \\
Exon 20 insertion & & 18 \\
His773_Val774insHisProHis & ACCCCCACC & 15 \\
p.Ala767delinsAlaSerValAsp & CAGCGTGGA & 9 \\
p.Val769_Asp770insAlaSerVal & TGGCCAGCG & 18 \\
p.Asp770_Asn771insLysAsp & GGACAA & 1 \\
\hline
\end{tabular}

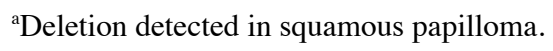

involved bronchoscope lavage specimens and had low RNA concentration. Cytological results were diverse. In all 9 cases, the conventional method could detect mutations while the NGS method was unable to detect mutations at $>1 \%$ frequency, except for one exon 19 deletion. For the specimens with remaining DNA sample available, sequencing was performed with TST15 by MiSeq. Although concentrations were low, all mutations detected with the conventional method were confirmed using TST15. In some cases, the variant allele frequency analyzed from RNA was greatly different than that obtained from DNA.
Minor mutations. Many minor mutations were detected from the NGS results. EGFR mutations $>10 \%$ of allele frequency are listed in Table VII. Although minor mutations were mostly accompanied by major mutations, such as L858R and exon 19 deletion $(21,22)$, gefitinib sensitizing mutations (L833V+H835L) and a resistance mutation (L747S) were also found $(23,24)$.

Mutations found in specimens with cytological class $3 b$ or lower. Cytological samples were frequently obtained from 
Table VI. Cases that showed discordance between NGS and conventional methods.

\begin{tabular}{|c|c|c|c|c|c|}
\hline Sample type & $\begin{array}{l}\text { RNA concentration } \\
(\mathrm{ng} / \mu \mathrm{l})\end{array}$ & Cytology & Conventional & NGS RNA (\%) & NGS DNA $(\%)$ \\
\hline Bronchoscope & 2.5 & III & ex19del & ND & - \\
\hline Bronchoscope & 2.2 & III & ex19del & E709K (1.4) & ex19del (1.2) \\
\hline Bronchoscope & 5.3 & II & ex19del & ND & - \\
\hline Bronchoscope & 3.4 & II & ex19del & ND & - \\
\hline Bronchoscope & 5.6 & III & ex19del & ex19del (0.36) & ex19del (1.7) \\
\hline Bronchoscope & 2.6 & IV & ex19del, T790M & ex19del (0.5), T790M (0.6) & ex19del (8.2), T790M 1.7) \\
\hline Bronchoscope & 0.7 & $\mathrm{~V}$ & ex19del, T790M & ex19del (42.4) & ex19del (17.5), T790M (1.3) \\
\hline Bronchoscope & 1.4 & IV & L858R & L858R (0.9) & L858R (1.3) \\
\hline Pleural effusion & 1.9 & $\mathrm{~V}$ & G719S, L861Q & ND & G719S (26.8), L861Q (26.6) \\
\hline
\end{tabular}

ND, not detectable.

Table VII. Minor mutations.

\begin{tabular}{|c|c|c|c|c|c|c|c|}
\hline Gender & $\begin{array}{l}\text { Sample } \\
\text { type }\end{array}$ & $\begin{array}{l}\text { RNA concentration } \\
(\mathrm{ng} / \mu \mathrm{l})\end{array}$ & Cytology & Histology & Sensitive (\%) & Resistant (\%) & Minor mutations (\%) \\
\hline M & FBS & 3.2 & $\mathrm{~V}$ & & ex19del (47.4) & $\mathrm{T} 790 \mathrm{M}(25.4)$ & $\mathrm{A} 750 \mathrm{P}(52.2)$ \\
\hline $\mathrm{F}$ & FBS & 5.5 & $\mathrm{~V}$ & & L858R (55.3) & & S720F (56.5) \\
\hline M & FBS & 3.4 & $\mathrm{~V}$ & & L858R (23.3) & & R776C (23.6) \\
\hline $\mathrm{F}$ & Surgery & 100 & & $\mathrm{AdCa}$ & ex19del (45.0) & & A755G (48.2) \\
\hline M & FBS & 5.9 & II & & & & A743T (55.3), H584R (13.5) \\
\hline M & FBS & 3.6 & $\mathrm{~V}$ & & & & L777P (16.0 \\
\hline M & Surgery & 100 & & $\mathrm{AdCa}$ & L858R (35.4) & & $\mathrm{R} 776 \mathrm{C}(38.0)$ \\
\hline $\mathrm{F}$ & Biopsy & 20 & & $\mathrm{AdCa}$ & ex19del (52.2) & $\mathrm{T} 790 \mathrm{M}(27.5)$ & T605N (43.4) \\
\hline M & FBS & 20 & $\mathrm{~V}$ & & & & $\mathrm{I} 586 \mathrm{~V}(16.2)$ \\
\hline M & Surgery & 20 & & $\mathrm{Ca}$ & G719C (86.7) & & S768I (85.4) \\
\hline $\mathrm{F}$ & FBS & 5.7 & II & & & & M825V (18.0), G901R (17.8) \\
\hline M & $\mathrm{PE}$ & 20 & II & & & & N816S (12.6), Q849L (11) \\
\hline M & Surgery & 20 & & $\mathrm{AdCa}$ & & & ex15del (43.8) \\
\hline M & FBS & 1.2 & $\mathrm{~V}$ & & & & Y827C (32.9) \\
\hline M & FBS & 1.2 & II & & & & K593R (10.2) \\
\hline $\mathrm{F}$ & $\mathrm{PE}$ & 20 & - & - & ex19del (37.4) & & A750P (38.9), G873E (16.2) \\
\hline M & FBS & 4.9 & $\mathrm{~V}$ & & & & G721S (11.3), L883fs (10.1) \\
\hline M & FBS & 3.4 & $\mathrm{~V}$ & & & & G863D (17.5) \\
\hline M & $\mathrm{PE}$ & 20 & $\mathrm{~V}$ & & & & A871S (14.9) \\
\hline M & FBS & 4.5 & II & & & & D800G (12.1) \\
\hline M & FBS & 1.6 & $\mathrm{~V}$ & & & & K754E (11.4) \\
\hline M & $\mathrm{PE}$ & 20 & $\mathrm{~V}$ & & L858R (32.8) & & $\mathrm{R} 776 \mathrm{C}(33.4)$ \\
\hline $\mathrm{F}$ & Surgery & 20 & & $\mathrm{AdCa}$ & & & L833V (72.3), H835L (69.7) \\
\hline M & FBS & 1.6 & II & & & & P631R (27.3) \\
\hline M & Surgery & 100 & & $\mathrm{AdCa}$ & ex19del (45.8) & & L747S (13.4) \\
\hline M & Surgery & 24.5 & & $\mathrm{Ca}$ & & & R705K (10.1) \\
\hline M & FBS & 3.9 & $\mathrm{~V}$ & & & & K642R (11.3) \\
\hline M & Surgery & 45.1 & & $\mathrm{AdCa}$ & G719A (32.6) & & R776H (29.5) \\
\hline $\mathrm{F}$ & FBS & 1.1 & $\mathrm{~V}$ & & & & I923T (33.9), K676R (27.6) \\
\hline M & FBS & 2.9 & $\mathrm{~V}$ & $\mathrm{AdCa}$ & L858R (28.9) & & E709G (30.5) \\
\hline $\mathrm{F}$ & FBS & 3 & $\mathrm{~V}$ & & & & E922K (12.0) \\
\hline $\mathrm{F}$ & $\mathrm{PE}$ & 20 & $\mathrm{~V}$ & & ex19del (49.4) & & K754E (50.0), K757R (50.0) \\
\hline M & Other & 3.8 & II & & & & N771S (10.8) \\
\hline $\mathrm{F}$ & Surgery & 20 & & $\mathrm{AdCa}$ & & & D916H (10.4) \\
\hline
\end{tabular}

FBS, fiberoptic bronchoscope; PE, pleural effusion. 
Table VIII. Mutations detected in cytological specimens under class $3 \mathrm{~b}$.

\begin{tabular}{lcccccc}
\hline Sample type & $\begin{array}{c}\text { RNA concentration } \\
(\mathrm{ng} / \mu \mathrm{l})\end{array}$ & Cytology & $\begin{array}{c}\text { EGFR } \\
\text { mutation }\end{array}$ & $\begin{array}{c}\text { Freqency } \\
(\%)\end{array}$ & $\begin{array}{c}\text { KRAS } \\
\text { mutation }\end{array}$ & $\begin{array}{c}\text { Freqency } \\
(\%)\end{array}$ \\
\hline Bronchoscope & 2.9 & II & L858R & 3 & & \\
Bronchoscope & 4.0 & II & & & G13C & 10.6 \\
Pleural effusion & 20 & II & & & G12C & 13.3 \\
Bronchoscope & 2.2 & II & & & G12S & 41.1 \\
Bronchoscope & 5.6 & IIIb & ex19del & 0.36 & & \\
Pleural effusion & 20 & IIIb & ex19del & 75.1 & & \\
Pleural effusion & 20 & IIIb & ex19del & 10.7 & & \\
Cerebrospinal fluid & 2.9 & IIIb & ex19del & 90.5 & & \\
Bronchoscope & 0.8 & IIIb & & & G12C & 42.5 \\
\hline
\end{tabular}

Table IX. Total cost of conventional and NGS methods.

\begin{tabular}{lcc}
\hline Procedure & Conventional method (US\$) & NGS method (US\$) \\
\hline No. of samples & 15 & 15 \\
Target region & EGFR: G719S, exon19del, T790M, & EGFR: exons 15-23 \\
& ex20ins, L858R, L861Q, EML4-ALK & KRAS: all CDS region \\
& & EMLA/KIF5b-ALK \\
& & KIF5b/CCDC6-RET \\
DNA/RNA extraction & 234.6 & 234.6 \\
Reverse transcription & 209.3 & 209.3 \\
PCR & 49.8 & 25.0 \\
Enzymatic treatment & 25.3 & - \\
Electrophoresis & 2.8 & - \\
Library construction & - & 911.2 \\
Sequencing & - & 483.9 \\
Total & 521.8 & $1,864.0$ \\
\end{tabular}

patients with suspected lung cancer, and in rare cases $E G F R$ mutations were detected in samples diagnosed as cytological class $3 \mathrm{~b}$ or lower. This sample was diagnosed as cancerous by genetic testing but 'suggestive of but not conclusive for malignancy' or 'no evidence of malignancy' by cytology. Extracting EGFR mutations confirmed by conventional methods and $K R A S$ mutations with an allele frequency $>10 \%$, resulted in 9 cases harboring EGFR or KRAS mutations below cytological class $3 \mathrm{~b}$ (Table VIII).

\section{Discussion}

In this study, we examined whether variant analysis by the NGS method using RNA was suitable for clinical use as genetic testing for lung cancer. Over 900 specimens were examined by the conventional method and NGS method in parallel over the course of one year. Moreover, we used solid samples, such as surgical and biopsy materials, as well as liquid samples, such as bronchoscope lavage and pleural effusion. Our results showed that the RNA-based method was practical for clinical examination as demonstrated by high sensitivity, short dura- tion (4 days), and low expense (approximately JP $\backslash 15,000$ or US\$144, as of June 2016) for each sample. The more detailed data are shown in Table IX. Supposing the number of the specimens per one week were 15 , total cost of NGS method was approximately 3.5 -fold. However, conventional method could only analyze six kinds of EGFR mutations and one kind of EML4-ALK fusion gene. On the other hand, NGS was able to analyze $E G F R$ (exons 15-23), KRAS (all CDS region) and five kinds of fusion genes. Especially, because mutations within exon 2 of KRAS are various, the analysis by NGS was efficient. Moreover, in conventional method, operation time increased in proportion to the increase of the target region, while almost unchanged in NGS method.

The positive rate of EGFR-TKI sensitizing mutations was $40 \%$ in surgical materials diagnosed as AdCa. The ratio was lower than one previous report (49\%) (25), but was similar to that of a recent study (26). The frequencies of $E M L 4 /$ $K I F 5 b-A L K$ and $K I F 5 b / C C D C 6-R E T$ were in total $2.2 \%$ among these patients, which was lower than that of a previous study $(3.8 \%)$ (13). The ratios of EGFR-TKI sensitizing mutations among smokers (58\%) and non-smokers (22\%) were 

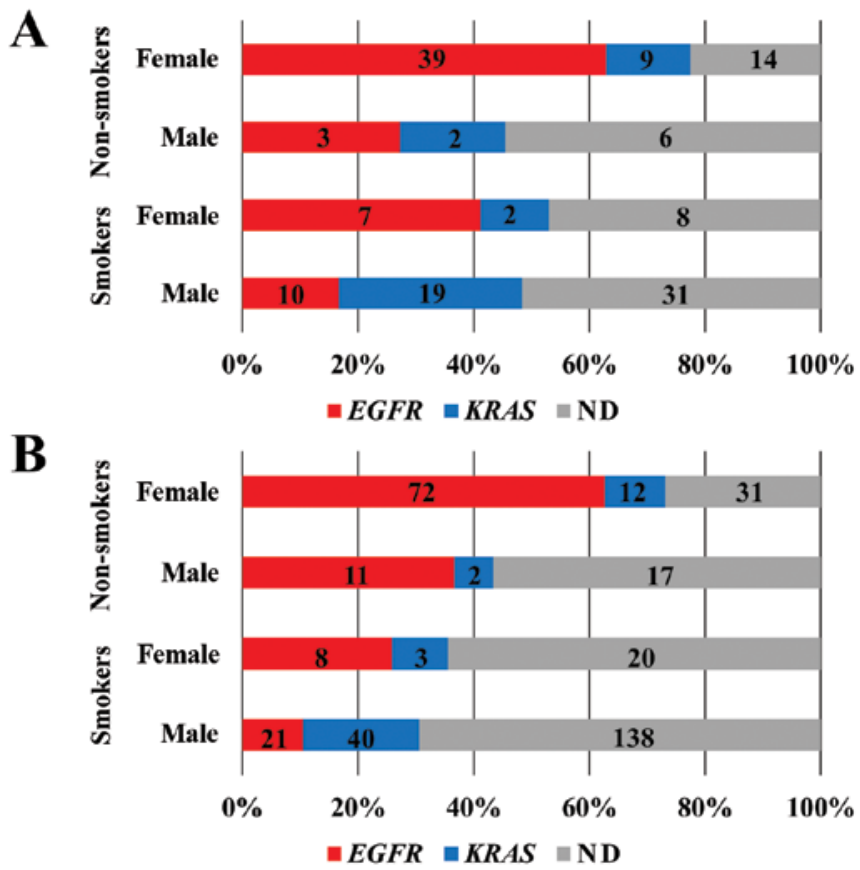

Figure 5. Distribution of EGFR and KRAS mutations by smoking status (A) Pathologically diagnosed AdCa or strongly suspected AdCa according to all materials. (B) AdCa diagnosed pathologically from surgical materials only. Numbers represent case numbers.

also less than that of a previous report (68\% and 31\%, respectively) (25). The positive rate of KRAS mutations (18\%) was higher than that from previous findings in Japan (7\%) and lower than that in the west (20\%) (27). Both EGFR and KRAS mutation frequencies were markedly different according to gender and smoking status (Fig. 5). EGFR-TKI sensitizing mutations were high in female non-smokers $(63 \%)$ and KRAS mutations were high in male smokers (32\%) (25).

Compared with the conventional method, the concordance rate of mutations was 99\% (892/901), excluding specimens with NGS failure. Almost all discordant cases were confirmed by DNA sequencing. Moreover, regarding the cases of NGS failure, 34 of these 38 specimens could still be analyzed by DNA sequencing. In a previous study, the frequency of the mutation allele in DNA was similar to the ratio of cancer cells. However, in RNA, the frequency is much higher because genes with driver mutations have high transcriptional activity (15). However, our results suggest that DNA sequencing could detect mutations with higher sensitivity than analyses using RNA. In some cases, the frequency of the mutant allele was higher in RNA analyses, thus the sensitivity of analyses using RNA might depend on experimental conditions. We propose the following three explanations for the increased sensitivity with DNA analyses: i) the small number of specimens may have been affected by experimental conditions; ii) even in specimens containing very few viable cells, necrotic tissue and dead cells still contained sufficient DNA; and iii) degradation of RNA may have occurred between sample collection to RNA extraction.

In the present study, $>30$ kinds of minor mutations were detected in the examined regions of EGFR. Although most of the minor mutations were accompanied by the presence of major mutations, some clinically relevant mutations were found, such as L833V+H835L (23) and L747S (24). With the advance of sequencing technology, a correlation between various mutations within the regions of EGFR from exon 18 to exon 21 and sensitivity $(28,29)$ or resistance $(24,30)$ of EGFR-TKIs has been reported. Regarding the major mutations, a previous study indicated that EGFR-TKI sensitivity decreased when the frequency of T790M-harboring cells exceeded 25\% (31), thus information on the allele frequency might be important for treatment. Moreover, the emergence of T790M after the administration of EGFR-TKIs was considered to contribute toward drug resistance (32), and EGFR C797S mutation indicated resistance against EGFR-TKIs targeting T790M (33). Therefore, genetic testing targeting a widespread region of EGFR could provide clinically useful information and could help develop a system to repeatedly analyze many genes and regions with efficiency and the ability to quantify. In addition, by examining various kind of specimens such as bronchoscope lavage and pleural effusion, the existence of cancer cells that did not emerge from cytodiagnosis was possibly revealed.

Several clinical trials of lung cancer with targeted KRAS mutations are ongoing (34). Recently, a small molecule with an effect on cancer cells harboring only the G12C mutation of $K R A S$ was discovered (35), and testing on individual KRAS mutations has become important for developing other therapeutic strategies (36).

Many candidate driver and resistance mutations were discovered in lung cancer (37-39) and genome-based diagnosis was attempted (40). Treatment selection with molecular profiling seems to bring a huge clinical benefit (41). So, some trials applying NGS to clinic are ongoing, for example SCRUM-Japan and NCI-MATCH (USA) (42). About the detection of fusion genes, superior sensitivity of NGS method was reported (43). Recently, a trial to detect mutation derived from a cancer cell was performed noninvasively by liquid biopsy such as plasma DNA (44). However, sensitivity of the diagnostic agents which FDA authorized was 5\%, and there is much false-negative. There were some reports about the usefulness of NGS in the liquid biopsy (45), and clinical application for the cancer treatment of NGS was expected in Japan.

The method used in this study was able to easily enrich broad protein-coding regions from RNA using PCR. In addition, this method could perform simultaneous detections of mutations and fusion genes and required fewer primer pairs than DNA sequence analyses. Sensitivity levels were approximately equal to those of conventional methods. Moreover, the NGS method with RNA sequence is cost-effective, as the sequencing cost per sample using this method is within the cost of 'Malignant tumor genetic testing' in Japan.

In conclusion, the strategy of analyzing mutations of target genes by the NGS method with RNA extracted from cancer cells for the purpose of developing treatment strategies compares favorably with the conventional method.

\section{Acknowledgements}

We acknowledge the work of past and present members of our department. This study was supported by JSPS KAKENHI 
grant no. 15K08335 and the National Cancer Center Research and Development Found grant no. 28-A-5.

\section{References}

1. Siegel RL, Miller KD and Jemal A: Cancer statistics, 2016. CA Cancer J Clin 66: 7-30, 2016.

2. Suda K, Tomizawa K, Yatabe Y and Mitsudomi T: Lung cancers unrelated to smoking: Characterized by single oncogene addiction? Int J Clin Oncol 16: 294-305, 2011.

3. Paez JG, Jänne PA, Lee JC, Tracy S, Greulich H, Gabriel S, Herman P, Kaye FJ, Lindeman N, Boggon TJ, et al: EGFR mutations in lung cancer: Correlation with clinical response to gefitinib therapy. Science 304: 1497-1500, 2004.

4. Lynch TJ, Bell DW, Sordella R, Gurubhagavatula S, Okimoto RA, Brannigan BW, Harris PL, Haserlat SM, Supko JG, Haluska FG, et al: Activating mutations in the epidermal growth factor receptor underlying responsiveness of non-small-cell lung cancer to gefitinib. N Engl J Med 350: 2129-2139, 2004.

5. Fukuoka M, Wu YL, Thongprasert S, Sunpaweravong P, Leong SS, Sriuranpong V, Chao TY, Nakagawa K, Chu DT, Saijo N, et al: Biomarker analyses and final overall survival results from a phase III, randomized, open-label, first-line study of gefitinib versus carboplatin/paclitaxel in clinically selected patients with advanced non-small-cell lung cancer in Asia (IPASS). J Clin Oncol 29: 2866-2874, 2011.

6. Soda M, Choi YL, Enomoto M, Takada S, Yamashita Y, Ishikawa S, Fujiwara S, Watanabe H, Kurashina K, Hatanaka H, et al: Identification of the transforming EML4-ALK fusion gene in non-small-cell lung cancer. Nature 448: 561-566, 2007.

7. Kwak EL, Bang YJ, Camidge DR, Shaw AT, Solomon B, Maki RG, Ou SH, Dezube BJ, Jänne PA, Costa DB, et al Anaplastic lymphoma kinase inhibition in non-small-cell lung cancer. N Engl J Med 363: 1693-1703, 2010.

8. Takeuchi K, Soda M, Togashi Y, Suzuki R, Sakata S, Hatano S, Asaka R, Hamanaka W, Ninomiya H, Uehara $\mathrm{H}$, et al: RET, ROS1 and ALK fusions in lung cancer. Nat Med 18: 378-381, 2012.

9. Falchook GS, Ordóñez NG, Bastida CC, Stephens PJ, Miller VA, Gaido L, Jackson T and Karp DD: Effect of the RET inhibitor vandetanib in a patient with RET fusion-positive metastatic nonSmall-cell Lung cancer. J Clin Oncol 34: e141-e144, 2016.

10. Shaw AT, Ou SH, Bang YJ, Camidge DR, Solomon BJ, Salgia R, Riely GJ, Varella-Garcia M, Shapiro GI, Costa DB, et al: Crizotinib in ROS1-rearranged non-small-cell lung cancer. N Engl J Med 371: 1963-1971, 2014

11. Li T, Kung HJ, Mack PC and Gandara DR: Genotyping and genomic profiling of non-small-cell lung cancer: Implications for current and future therapies. J Clin Oncol 31: 1039-1049, 2013.

12. Papadopoulou E, Tsoulos N, Tsirigoti A, Apessos A, Agiannitopoulos K, Metaxa-Mariatou V, Zarogoulidis K, Zarogoulidis P, Kasarakis D, Kakolyris S, et al: Determination of EGFR and KRAS mutational status in Greek non-small-cell lung cancer patients. Oncol Lett 10: 2176-2184, 2015.

13. Takeda M, Sakai K, Terashima M, Kaneda H, Hayashi H, Tanaka K, Okamoto K, Takahama T, Yoshida T, Iwasa T, et al: Clinical application of amplicon-based next-generation sequencing to therapeutic decision making in lung cancer. Ann Oncol 26: 2477-2482, 2015

14. Shao D, Lin Y, Liu J, Wan L, Liu Z, Cheng S, Fei L, Deng R, Wang J, Chen X, et al: A targeted next-generation sequencing method for identifying clinically relevant mutation profiles in lung adenocarcinoma. Sci Rep 6: 22338, 2016.

15. Wilkerson MD, Cabanski CR, Sun W, Hoadley KA, Walter V, Mose LE, Troester MA, Hammerman PS, Parker JS, Perou CM, et al: Integrated RNA and DNA sequencing improves mutation detection in low purity tumors. Nucleic Acids Res 42: e107, 2014

16. Akagi K, Sakai H, Sudo J, Hommura Y, Kurimoto F, Komagata H, Akiyama $\mathrm{H}$ and Yoneda S: Simple method to detect important epidermal growth factor receptor gene mutations with bronchoscopic specimens of lung cancer patients for gefitinib treatment. Target Oncol 2: 145-151, 2007.

17. Higasa K, Miyake N, Yoshimura J, Okamura K, Niihori T, Saitsu H, Doi K, Shimizu M, Nakabayashi K, Aoki Y, et al: Human genetic variation database, a reference database of genetic variations in the Japanese population. J Hum Genet 61: 547-553, 2016.
18. Nagasaki M, Yasuda J, Katsuoka F, Nariai N, Kojima K, Kawai Y, Yamaguchi-Kabata Y, Yokozawa J, Danjoh I, Saito S, et al; ToMMo Japanese Reference Panel Project: Rare variant discovery by deep whole-genome sequencing of 1,070 Japanese individuals. Nat Commun 6: 8018, 2015.

19. Cerami E, Gao J, Dogrusoz U, Gross BE, Sumer SO, Aksoy BA, Jacobsen A, Byrne CJ, Heuer ML, Larsson E, et al: The cBio cancer genomics portal: An open platform for exploring multidimensional cancer genomics data. Cancer Discov 2: 401-404, 2012.

20. Gao J, Aksoy BA, Dogrusoz U, Dresdner G, Gross B, Sumer SO, Sun Y, Jacobsen A, Sinha R, Larsson E, et al: Integrative analysis of complex cancer genomics and clinical profiles using the cBioPortal. Sci Signal 6: pl1, 2013.

21. Baek JH, Sun JM, Min YJ, Cho EK, Cho BC, Kim JH, Ahn MJ and Park K: Efficacy of EGFR tyrosine kinase inhibitors in patients with EGFR-mutated non-small cell lung cancer except both exon 19 deletion and exon 21 L858R: A retrospective analysis in Korea. Lung Cancer 87: 148-154, 2015.

22. Wu SG, Chang YL, Hsu YC, Wu JY, Yang CH, Yu CJ, Tsai MF, Shih JY and Yang PC: Good response to gefitinib in lung adenocarcinoma of complex epidermal growth factor receptor (EGFR) mutations with the classical mutation pattern. Oncologist 13: 1276-1284, 2008.

23. Yang TY, Tsai CR, Chen KC, Hsu KH, Lee HM and Chang GC: Good response to gefitinib in a lung adenocarcinoma harboring a heterozygous complex mutation of L833V and H835L in epidermal growth factor receptor gene. J Clin Oncol 29: e468-e469, 2011.

24. Costa DB, Schumer ST, Tenen DG and Kobayashi S: Differential responses to erlotinib in epidermal growth factor receptor (EGFR)-mutated lung cancers with acquired resistance to gefitinib carrying the L747S or T790M secondary mutations. J Clin Oncol 26: 1182-1184, author reply 1184-1186, 2008.

25. Kosaka T, Yatabe Y, Endoh H, Kuwano H, Takahashi T and Mitsudomi T: Mutations of the epidermal growth factor receptor gene in lung cancer: Biological and clinical implications. Cancer Res 64: 8919-8923, 2004.

26. Suzuki A, Mimaki S, Yamane Y, Kawase A, Matsushima K, Suzuki M, Goto K, Sugano S, Esumi H, Suzuki Y, et al: Identification and characterization of cancer mutations in Japanese lung adenocarcinoma without sequencing of normal tissue counterparts. PLoS One 8: e73484, 2013.

27. Jänne PA, Shaw AT, Pereira JR, Jeannin G, Vansteenkiste J, Barrios C, Franke FA, Grinsted L, Zazulina V, Smith P, et al: Selumetinib plus docetaxel for KRAS-mutant advanced non-small-cell lung cancer: A randomised, multicentre, placebocontrolled, phase 2 study. Lancet Oncol 14: 38-47, 2013.

28. Wu JY, Yu CJ, Chang YC, Yang CH, Shih JY and Yang PC: Effectiveness of tyrosine kinase inhibitors on 'uncommon' epidermal growth factor receptor mutations of unknown clinical significance in non-small cell lung cancer. Clin Cancer Res 17: 3812-3821, 2011.

29. Klughammer B, Brugger W, Cappuzzo F, Ciuleanu T, Mok T, Reck M, Tan EH, Delmar P, Klingelschmitt G, Yin AY, et al: Examining treatment outcomes with erlotinib in patients with advanced non-small cell lung cancer whose tumors harbor uncommon EGFR mutations. J Thorac Oncol 11: 545-555, 2016.

30. Bean J, Riely GJ, Balak M, Marks JL, Ladanyi M, Miller VA and Pao W: Acquired resistance to epidermal growth factor receptor kinase inhibitors associated with a novel T854A mutation in a patient with EGFR-mutant lung adenocarcinoma. Clin Cancer Res 14: 7519-7525, 2008.

31. Chmielecki J, Foo J, Oxnard GR, Hutchinson K, Ohashi K, Somwar R, Wang L, Amato KR, Arcila M, Sos ML, et al: Optimization of dosing for EGFR-mutant non-small cell lung cancer with evolutionary cancer modeling. Sci Transl Med 3: 90ra59, 2011.

32. Hata AN, Niederst MJ, Archibald HL, Gomez-Caraballo M, Siddiqui FM, Mulvey HE, Maruvka YE, Ji F, Bhang HE, Krishnamurthy Radhakrishna V, et al: Tumor cells can follow distinct evolutionary paths to become resistant to epidermal growth factor receptor inhibition. Nat Med 22: 262-269, 2016.

33. Thress KS, Paweletz CP, Felip E, Cho BC, Stetson D, Dougherty B Lai Z, Markovets A, Vivancos A, Kuang Y, et al: Acquired EGFR C797S mutation mediates resistance to AZD9291 in non-small cell lung cancer harboring EGFR T790M. Nat Med 21: 560-562, 2015.

34. Kempf E, Rousseau B, Besse B and Paz-Ares L: KRAS oncogene in lung cancer: Focus on molecularly driven clinical trials. Eur Respir Rev 25: 71-76, 2016.

35. Ostrem JM, Peters U, Sos ML, Wells JA and Shokat KM: K-Ras(G12C) inhibitors allosterically control GTP affinity and effector interactions. Nature 503: 548-551, 2013. 
36. Hames ML, Chen H, Iams W, Aston J, Lovly CM and Horn L: Correlation between KRAS mutation status and response to chemotherapy in patients with advanced non-small cell lung cancer. Lung Cancer 92: 29-34, 2016.

37. Pao $\mathrm{W}$ and Girard N: New driver mutations in non-small-cell lung cancer. Lancet Oncol 12: 175-180, 2011

38. Suda K, Mizuuchi H, Murakami I, Uramoto H, Tanaka F, Sato K Takemoto T, Iwasaki T, Sekido Y, Yatabe Y, et al: CRKL amplification is rare as a mechanism for acquired resistance to kinase inhibitors in lung cancers with epidermal growth factor receptor mutation. Lung Cancer 85: 147-151, 2014.

39. Kim GW, Song JS, Choi CM, Rho JK, Kim SY, Jang SJ, Park YS Chun SM, Kim WS, Lee JS, et al: Multiple resistant factors in lung cancer with primary resistance to EGFR-TK inhibitors confer poor survival. Lung Cancer 88: 139-146, 2015.

40. Clinical Lung Cancer Genome Project (CLCGP); Network Genomic Medicine (NGM): A genomics-based classification of human lung tumors. Sci Transl Med 5: 209ra153, 2013.

41. Barlesi F, Mazieres J, Merlio JP, Debieuvre D, Mosser J, Lena H, Ouafik L, Besse B, Rouquette I, Westeel V, et al; Biomarkers France contributors: Routine molecular profiling of patients with advanced non-small-cell lung cancer: Results of a 1-year nationwide programme of the French Cooperative Thoracic Intergroup (IFCT). Lancet 387: 1415-1426, 2016.
42. Colwell J: NCI-MATCH trial draws strong interest. Cancer Discov 6: 334, 2016.

43. Dacic S, Villaruz LC, Abberbock S, Mahaffey A, Incharoen P and Nikiforova MN: ALK FISH patterns and the detection of ALK fusions by next generation sequencing in lung adenocarcinoma. Oncotarget 7: 82943-82952, 2016.

44. Mok TS, Wu YL, Ahn MJ, Garassino MC, Kim HR, Ramalingam SS, Shepherd FA, He Y, Akamatsu H, Theelen WS, et al; AURA3 Investigators: Osimertinib or platinum-pemetrexed in EGFR T790M-positive lung cancer. N Engl J Med: December 6, 2016 (Epub ahead of print). doi: 10.1056/NEJMoa1612674.

45. Paweletz CP, Sacher AG, Raymond CK, Alden RS, O'Connell A, Mach SL, Kuang Y, Gandhi L, Kirschmeier P, English JM, et al: Bias-corrected targeted next-generation sequencing for rapid, multiplexed detection of actionable alterations in cell-free DNA from advanced lung cancer patients. Clin Cancer Res 22: 915-922, 2016. 